\title{
ANALISIS IMPLEMENTASI SISTEM PEMBIAYAAN IB MIKRO SYARIAH PADA BANK DKI SYARIAH CABANG DEPOK
}

\author{
Firyal Afifah Rochmano ${ }^{1}$, Suryani ${ }^{2}$ \& Ade Nur Rohim ${ }^{3}$ \\ ${ }^{1}$ \&3 Fakultas Ekonomi dan Bisnis, Universitas Pembangunan Nasional Veteran Jakarta \\ ${ }^{2}$ Fakultas Ekonomi dan Bisnis Islam, Universitas Islam Negeri Sultan Maulana Hasanuddin Banten \\ Email :firyal.afifah@upnvj.ac.id, suryani@uinbanten.ac.id, adenurrohim@upnvj.ac.id
}

\begin{abstract}
ABSTRAK
Usaha Mikro Kecil atau UMK berperan sebagai penopang perekonomian rakyat dimana pada saat masa krisis unit usaha ini tidak terdampak begitu besar, melainkan menjadi solusi untuk kebangkitan ekonomi nasional di Indonesia dan di beberapa negara. Hadir dengan pengaruh yang besar namun, UMK juga memiliki kesulitan dalam mendapatkan pendanaan pada modal usaha, sehingga perlu adanya peran lembaga pembiayaan dengan bentuk atau model pembiayaan berbasis syariah yang didasari nilai-nilai Islam. Penelitian ini bertujuan untuk mengetahui implementasi sistem pembiayaan IB mikro syariah di Bank DKI Syariah Cabang Depok serta melihat efektivitas pembiayaan syariah dalam memberdayakan UMK berbasis syariah. Metode yang digunakan yaitu metode kualitatif deskriptif dengan pendekatan studi kasus. Hasil penelitian menunjukan bahwa pembiayaan IB mikro syariah di Bank DKI Syariah Cabang Depok dilaksanakan dengan sistem akad murabahah dan ijarah muntahiya bit tamlik (IMBT). Pembiayaan IB mikro syariah telah efektif dalam memberdayakan UMK berbasis syariah dengan menerapkan aspek fungsi pembiayaan, perencanaan pembiayaan, peraturan pembiayaan, dan tujuan pembiayaan.
\end{abstract}

Kata Kunci : Bank Syariah, UMK, Pembiayaan Syariah.

\begin{abstract}
Micro, Small and Medium Enterprises or MSEs play a role as a support for the people's economy where even during times of crisis this business unit is not affected so much, but instead becomes a solution for the revival of the national economy in Indonesia and in several countries. Comes with great influence, however, MSEs also have difficulties in obtaining funding for business capital, so there is a need for a role for financing institutions with sharia-based forms or models of financing based on Islamic values. This study aims to determine the implementation of the Sharia Micro IB financing system at Bank DKI Syariah Depok Branch and to see the effectiveness of sharia financing in empowering sharia-based MSEs. The method used is descriptive qualitative method with a case study approach. The results of the study show that the financing of Sharia Micro IB at Bank DKI Syariah Depok Branch is carried out with the murabahah and ijarah vomitiya bit tamlik (IMBT) contract systems. Sharia Micro IB Financing has been effective in empowering sharia-based MSEs by implementing aspects of the financing function, financing planning, financing regulations, and financing objectives.
\end{abstract}

Keywords: Islamic Banks, Micro and Small Enterprises, Sharia Financing, 


\section{PENDAHULUAN}

Perkembangan roda perekonomian
berkembang umumnya diikuti oleh perkembangan industri juga perekonomian rakyat seperti Usaha Mikro Kecil (UMK). Beberapa keadaan krisis nasional di banyak negara terselamatkan ketika masyarakat telah mandiri dalam sektor Usaha Mikro Kecil (UMK), sehingga peranannya bagi pertumbuhan perekonomian negara menjadi sangat penting. Sektor Usaha Mikro Kecil (UMK) menjadi penolong bagi kondisi prekonomian nasional, yang setidaknya sudah terdapat sebanyak lebih dari 64 juta unit usaha, serta telah berkontribusi kepada 97 persen terhadap seluruh penyerapan tenaga kerja, dan telah memberikan 60 persen bagi PDB nasional Indonesia (Kementerian Koperasi dan UKM RI, 2020).

Usaha Mikro Kecil (UMK) memiliki peran yang strategis dalam perekonomian untuk meningkatkan penyerapan tenaga kerja, pemerataan pendapatan, serta pertumbuhan perekonomian nasional. Peran strategis Usaha Mikro Kecil (UMK) sangatlah penting, khususnya bagi negara berkembang seperti Indonesia. Mengingat sifatnya yang padat karya, sektor ini dapat efektif menciptakan lapangan kerja, dan membantu meningkatkan perekonomian (Permana, 2017).

Memiliki manfaat strategis bagi perekonomian, Usaha Mikro Kecil (UMK) sendiri juga memiliki tantangan, yaitu terletak pada permodalan usahanya, sehingga diperlukannya kebijakan yang mendukung fungsi peran lembaga pembiayaan bagi Usaha Mikro Kecil (UMK) (Kementerian Perdagangan, 2013). Hal ini dikarenakan para pelaku usaha tersebut banyak mengalami kesulitan dalam pengembangan usaha, seperti ketidakmampuan dalam memenuhi kegiatan produksi atau keterbatasan modal. Oleh karenanya, jika hal ini tidak diatasi, maka besar kemungkinan impian memiliki Usaha Mikro Kecil (UMK) besar dan berkarakter tidak dapat terealisasikan (Hidayati, 2018). Oleh sebab itu, penting hadirnya lembaga pembiayaan seperti bank atau non-bank bagi Usaha Mikro Kecil (UMK).

Hadirnya salah satu lembaga pembiayaan seperti perbankan, sangat penting guna memenuhi kebutuhan permodalan bagi Usaha Mikro Kecil (UMK). Bank dapat memberikan pembiayaan permodalan kepada nasabah pelaku usaha tersebut agar dapat mengembangkan usahanya (Imronah, 2019). Pembiayaan yang dilakukan bank, dapat menjadi salah satu upaya dalam pengembangan sektor Usaha Mikro Kecil (UMK) tersebut, sehingga peran lembaga pembiayaan serta kebijakan yang mendukung hal tersebut agar dapat menjadi salah satu upaya pengembangannya (Kementerian Perdagangan, 2013).

Potensi yang dimiliki Usaha Mikro Kecil (UMK), serta dominasi masyarakat Muslim Indonesia, maka bank syariah dengan pembiayaan syariah menjadi salah satu model produk pembiayaan yang memungkinkan terbentuknya fenomena niat masyarakat dalam menggunakan pembiayaan modal berbasis syariah (Hidayati, 2018). Potensi bank syariah semakin besar karena adanya paradigma yang telah lama bergulir di tengah masyarakat Muslim bahwa, bentuk bunga pada bank termasuk kedalam kategori riba, sehingga terbentuknya minat sebagai seorang Muslim untuk tidak melakukan transaksi pada lembaga perbankan konvensional (Ratnawati dan Mursid, 2011).

Pembiayaan pada bank konvensional dengan sistem bunga dianggap sangat merugikan nasabah pelaku Usaha Mikro Kecil (UMK), karena ketika sedang mengalami kerugian dan keuntungan nasabah juga tidak stabil, hal tersebut menimbulkan keengganan untuk mengajukan pinjaman pada bank konvensional (Murdaningsih, 2019). Sehingga hadirnya produk pembiayaan pada bank syariah, sistem yang digunakan pada pembiayaan Usaha Mikro Kecil (UMK), dengan menggunakan sistem bagi hasil. Kedua belah pihak antara bank dengan nasabah menyepakati keuntungan saat awal akad. Hal 
tersebut memudahkan para pelaku Usaha Mikro Kecil (UMK) dalam melakukan pembiayaannya (Sofyan, 2019).

Beberapa hasil penelitian yang membahas mengenai pentingnya lembaga keuangan perbankan syariah dalam melakukan pembiayaan pada sektor Usaha Mikro Kecil (UMK), didapatkan sistem pembiayaan yang digunakan perbankan syariah yang menggunakan akad mudhrabah dengan sistem atau prinsip bagi hasil dapat mempermudah nasabah pelaku sektor Usaha Mikro Kecil (UMK), karena mengingat kaum yang lemah pada model pembiayaan syariah lebih diutamakan dengan melihat dasar prinsip syariah (Muheramtohadi, 2017).

Berdasarkan penjelasan tersebut, pembiayaan syariah yang digunakan pelaku sektor Usaha Mikro Kecil (UMK) dapat sangat membantu dalam meningkatkan pendapatannya, terlebih sektor Usaha Mikro Kecil (UMK) sangat diperlukan sebagai penggerak roda perekonomian suatu negara. Oleh karena itu, peneliti merumuskan masalah penelitian, yaitu bagaimana implementasi sistem pembiayaan IB mikro syariah pada Bank DKI Syariah Cabang Depok serta efektivitasnya dalam memberdayakan Usaha Mikro Kecil (UMK) berbasis syariah.

\section{TINJAUAN PUSTAKA}

\section{Usaha Mikro Kecil (UMK) Berbasis Syariah}

Usaha Mikro Kecil atau UMK merupakan segmen terbesar pelaku ekonomi nasional, merupakan usaha marginal yaitu usaha yang masih menggunakan teknologi sederhana, dan dengan tingkat modal juga akses kredit rendah, serta kecendrungan orientasi pada usaha lokal (Weya et al, 2020). Prinsip wirausaha syariah merupakan bentuk pernyataan atas kebenaran pokok, yaitu dengan memberikan petunjuk dalam sebuah pemikiran atau tindakan, sehingga prinsip ini merupakan bentuk yang dijalankan berdasarkan ketentuan Allah SWT di dalam Al-Quran serta Hadist terkait perdagangan atau bisnis kepada kebenaran mutlak yang mengacu prinsip kewirausahaan Rasulullah SAW.

Transaksi dilakukan harus melindungi lima hal yang penting yaitu, diin (agama), jiwa, kehormatan, akal dan harta. Oleh karena itu Islam berupaya untuk membentuk norma-norma yang sesuai dengan ketepatan lima perkata tersebut (Farid, 2017).

Sehingga dapat disimpulkan bahwa Usaha Mikro Kecil (UMK) syariah adalah usaha yang tidak terlepas dari prinsip syariah, sebagai bagian dari sistem ekonomi syariah. Sehingga di dalam operasionalnya bisnis Usaha Mikro Kecil (UMK) berada di dalam koridor prinsip-prinsip: keadilan, yaitu berbagai keuntungan yang didasarkan pada penjualan riil sesuai kontribusi serta resiko masing-masing pihak yang didasari pada prinsip Islam (Suwardi dan Boediningsih, 2020).

\section{Pembiayaan Murabahah}

Murabahah merupakan akad jual beli barang yang dimana dalam pelaksanaannya dilakukan dengan menyatakan harga perolehan dan keuntungan (margin) yang sudah disepakati oleh penjual dan pembeli dimana pembayaran dapat dilakukan secara tunai atau cicilan (Satria, 2018).

Murabahah dapat dilakukan dengan menggunakan dua cara yaitu, melalui pembelian dengan pemesanan dan juga tanpa pemesanan, di dalam menentukan margin bagi bank yaitu dengan melalui persetujuan jual beli suatu barang dengan harga sebesar harga pokok yang ditambahkan dengan keuntungan yang telah disepakati bersama, dimana persetujuan tersebut juga meliputi cara pembayaran, hal tersebut memungkinkan lembaga keuangan syariah untuk memperoleh profit berupa pendapatan penjualan dari harga pokok yang sudah ditentukan oleh pihak lembaga keuangan melalui pembiayaan murabahah (Felani dan Setiawani, 2016). 


\section{Pembiayaan Ijarah Al-Muntahiya bit Tamlik (IMBT)}

Ijarah Al-Muntahiya bit Tamlik adalah salah satu bentuk transaksi yang memiliki sifat saling menolong, dan terdapat landasannya di dalam Al-Quran dan Hadist. Sama seperti pembiayaan murabahah, ijarah termasuk kedalam kategori Natural Certainty Contract, yang dapat dasarnya merupakan akad jual beli, dengan perbedaan pada objek transaksi yang diperjual belikan di dalam objek transaksi tersebut, dalam murabahah objek transaksinya adalah barang seperti mobil, rumah dan lain-lain. Sedangkan ijarah objek transaksinya adalah jasa, seperti manfaat atas tenaga kerja (Chasanah et al, 2020). Berdasarkan pasal 19 ayat (1) Undang-undang Perbankan Syariah, Ijarah Al-Muntahiya bit Tamlik (IMBT) merupakan akad penyediaan dana dalam rangka memindahkan hak guna atau manfaat dari suatu barang dan jasa yang didasarkan pada transaksi sewa dengan opsi pemindahan kepemilikan atas barang.

Ijarah Al-Muntahiya bit Tamlik (IMBT) merupakan akad sewa menyewa diantara pemilik objek sewa dengan penyewa untuk mendapatkan suatu imbalan terhadap objek sewa yang disewakan dengan opsi kepemilikan atas objek sewa pada waktu tertentu sesuai dengan akad sewanya (Dzubyan et al, 2017).

\section{Pembiayaan Syariah}

Hubungan pinjam-meminjam dalam Islam tidak dilarang, bahkan dianjurkan agar dapat terjadi hubungan yang saling menguntungkan. Sehingga setiap pinjaman yang menghasilkan manfaat selama kegiatan pinjam meminjam tersebut berupa akad sosial dan bukan komersial, yang artinya jika seseorang meminjam sesuatu tidak diperbolehkan untuk memberikan tambahan atas pokok pinjamannya. Oleh karena itu, kelembagaan pembiayaan syariah adalah lembaga pembiayaan yang dalam menjalankan usahanya didasarkan atas hukum syariah. Berikut beberapa ciri khas lembaga pembiayaan syariah:
1. Bebas atas bunga.

2. Berprinsip bagi hasil dan resiko (profit and risk sharing).

3. Perhitungan bagi hasil dilakukan pada saat transaksi berakhir, sehingga perhitungan dapat dilakukan setelah adanya keuntungan riil (Saragih, 2017).

\section{Efektivitas}

Efektivitas adalah kemampuan dalam melaksanakan tugas, fungsi (operasi kegiatan program atau misi) dari suatu organisasi dan sejenisnya yang tidak memiliki tekanan atau ketegangan diantara pelaksanaannya. Oleh karena itu efektivitas menjadi indikator tercapainya tujuan suatu organisasi atau lembaga di dalam mencapai tujuannya, karena tujuan akan tercapai jika segala kegiatannya telah berjalan secara efektif yang didukung oleh faktor-faktor pendukung efektivitas (Bakulu et al, 2021).

Efektivitas dapat diukur menggunakan 4 aspek yaitu;

1. Aspek tugas atau fungsi, dimana lembaga dikatakan efektif jika telah melaksanakan tugas atau fungsinya.

2. Aspek rencana atau program, yang dimaksud rencana disini adalah kegiatan yang terprogram, dan dapat dikatakan efektif jika seluruh perencanaan dapat dilaksanakan.

3. Aspek ketentuan dan peraturan, efektivitas suatu program dapat dilihat melalui berfungsi atau tidaknya suatu aturan yang sudah dibuat dalam rangka untuk menjaga keberlangsungan proses kegiatannya.

4. Aspek tujuan atau kondisi ideal, suatu program dapat dikatakan efektif yaitu ketika tujuan atau kondisi ideal yang telah ditetapkan dapat dicapai. Aspek ini dapat dilihat dari presentasi yang dicapai dari kegiatan tersebut (Muasaroh, 2010).

\section{METODE PENELITIAN}

Model penelitian ini menggunakan metode penelitian deskriptif kualitatif 
dengan pendekatan studi kasus. Sumber data didapatkan dengan data primer melalui wawancara, observasi serta dokumentasi secara langsung kepada pihak Bank DKI Syariah Cabang Depok dan nasabah pembiayaan IB mikro syariah. Sedangkan data sekunder dalam penelitian ini didapatkan peneliti melalui penelitianpenelitian terdahulu yang serupa.

\section{HASIL DAN PEMBAHASAN}

\section{Pembiayaan IB Mikro Syariah pada Bank DKI Syariah Cabang Depok}

Pembiayaan IB Mikro Syariah merupakan permodalan yang diberikan Bank DKI Syariah kepada nasabah yang membutuhkan permodalan dalam melakukan usahanya terutama pada pelaku sektor Usaha Mikro Kecil (UMK) berdasarkan prinsip syariah Islam.

\section{Gambar 1. Brosur Pembiayaan IB Mikro Syariah}

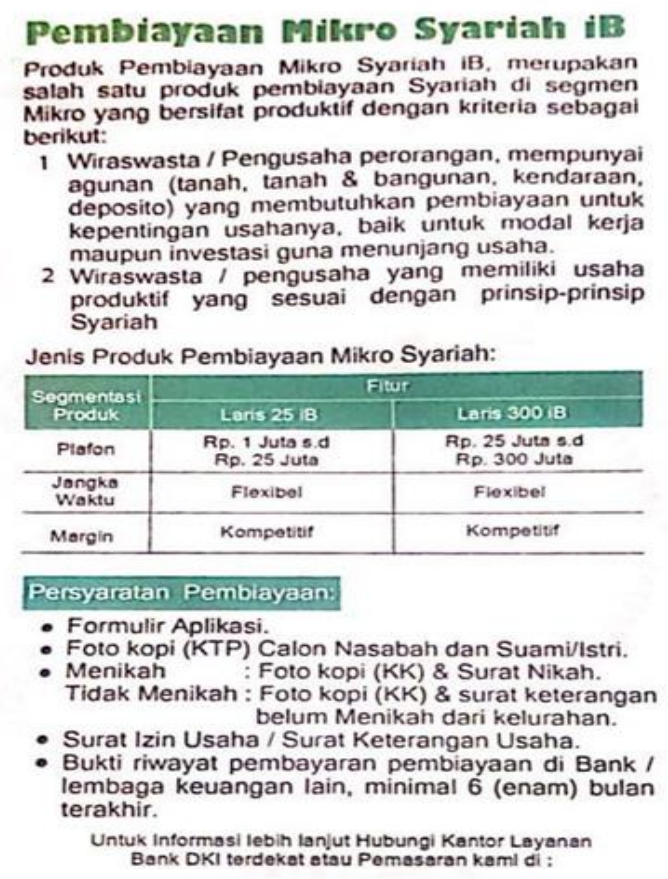

Sumber: Dokumentasi Pribadi (2021)

Berdasarkan Gambar 1 di atas, pembiayaan IB mikro syariah ialah salah satu produk pembiayaan syariah di segmen mikro yang bersifat produktif dengan beberapa kriteria.

Hal tersebut sejalan dengan pernyataan Khoeriyah (2016), bahwa pembiayaan syariah merupakan pembiayaan yang bersumber pada prinsip syariah dengan persetujuan ataupun konvensi antara industri pembiayaan dengan suatu bagian lain dimana mengharuskan bagian yang dibiayai mengembalikan pembiayaan tersebut pada tenor tertentu dengan balasan ataupun imbalan bagi hasil.
Pembiayaan IB Mikro Syariah memiliki 2 jenis pembiayaan. Pertama, pembiayaan laris 25 IB merupakan pengajuan pembiayaan yang plafonnya mulai dari Rp. 1.000.000,00 - Rp. 25.000.000,00 yang perjanjian pembiayaannya dilakukan dibawah tanda tangan, ketika penandatanganan pembiayaan surat pengakuan hutang dan turunannya wajib didokumentasikan dalam bentuk foto.

Sedangkan yang kedua, untuk pembiayaan laris 300 IB adalah pengajuan pembiayaan yang plafonnya mulai dari $\mathrm{Rp}$. 25.000.000,00 - Rp. 300.000.000,00 dimana jika perjanjian pembiayaannya di atas plafon Rp. 200.000.000,00 maka harus dibuat 
berdasarkan undang-undang berwenang (notariil).

Jangka waktu dan margin kedua jenis pembiayaan IB Mikro Syariah, yaitu fleksibel antara 1-5 tahun, sedangkan untuk marginnya adalah kompetitif dimana margin ditentukan sesuai dengan kebijakan pusat dan pada saat ini Bank DKI Syariah menggunakan angsuran Pemulihan Ekonomi Nasional (PEN) yang berubah-ubah setiap bulannya.

Pihak bank mengatasi angsuran macet ketika ada nasabah yang mengalami hal tersebut ialah dengan melakukan pendekatan dan memberikan solusi kepada pihak nasabah, bank dan nasabah berhubungan layaknya keluarga sehingga, nasabah dapat terbuka kepada pihak bank jika mengalami kekurangan dana pada saat membayar angsuran.

\section{Sistem Pembiayaan IB Mikro Syariah pada Bank DKI Syariah Cabang Depok}

Sistem pembiayaan IB Mikro Syariah pada Bank DKI Syariah menggunakan dua sistem akad pembiayaan, yaitu sistem murabahah dan sistem Ijarah Muntahiya Bit Tamlik atau IMBT.

\section{Sistem Pembiayaan Akad Murabahah.}

Bank DKI Syariah Cabang Depok menerapkan sistem pembiayaan murabahah di dalam pembiayaan IB Mikro Syariah, dimana hal tersebut merupakan transaksi jual beli untuk suatu barang sebesar harga perolehan barang ditambah dengan margin yang telah disepakati oleh para pihak, bank menginformasikan terlebih dahulu harga perolehan barang tersebut kepada nasabah.

Sistem pembiayaan akad murabahah yang digunakan pembiayaan IB Mikro Syariah pada Bank DKI Syariah sudah sesuai dengan ketentuan yang dijelaskan oleh fatwa DSN MUI No: 111/DSN-MUI/IX/2017 bahwasannya akad murabahah merupakan jual beli pada suatu barang dimana pihak penjual (al-Ba'i) menegaskan harga belinya kepada pihak calon pembeli (al-Musytari) dan pembeli membayarnya dengan harga yang lebih besar dari harga beli penjual sebagai laba bagi penjual.

Nasabah dalam menggunakan pembiayaan harus menyertakan barang jaminan seperti sertifikat kepemilikan atau sertifikat hak guna bangunan atau jaminan BPKB kendaraan.

\section{Sistem Pembiayaan Akad Ijarah Muntahiya Bit Tamlik (IMBT)}

Ijarah Muntahiya Bit Tamlik atau IMBT menurut Dzubyan (2017), merupakan akad sewa menyewa diantara pemilik objek sewa dengan penyewa untuk mendapatkan suatu imbalan terhadap objek sewa yang disewakan dengan opsi kepemilikan atas objek sewa pada waktu tertentu sesuai dengan akad sewanya.

Sistem akad tersebut sangat jarang digunakan pada Bank DKI Syariah, rata-rata nasabah pembiyaan IB Mikro Syariah menggunakan sistem murabahah. Sistem Ijarah Muntahiya Bit Tamlik (IMBT) biasanya digunakan ketika adanya nasabah yang pindah pembiayaan syariah dari bank syariah lain kepada Bank DKI Syariah. Sistem Ijarah Muntahiya Bit Tamlik (IMBT) yang diterapkan pada Bank DKI Syariah Cabang Depok ialah menggunakan akad qardh, dimana pihak Bank DKI Syariah melakukan pengalihan atau pelunasan hutang kepada pihak bank syariah nasabah sebelumnya sampai adanya informasi pelunasan hutang tersebut dari bank syariah sebelumnya, setelah itu pihak Bank DKI Syariah menggunakan akad ba'i yang dimana nasabah tersebut melakukan jual beli barangnya kepada pihak bank, kemudian pelunasan angsurannya menggunakan sistem akad Ijarah Muntahiya Bit Tamlik (IMBT). Nasabah melakukan pelunasan angsuran dengan sistem akad Ijarah muntahiya bit tamlik (IMBT) yang artinya nasabah melakukan sewa atas agunan tersebut, selanjutnya pihak bank menggunakan akad $b a ' i$ kedua yang merupakan agunan tersebut dihibahkan kepada nasabah.

Sistem pembiayaan akad Ijarah
muntahiya bit tamlik (IMBT) yang


digunakan pada pembiayaan ini sama dengan teori yang diungkapkan Ramadhani (2019) bahwasannya, pembiayaan Ijarah muntahiya bit tamlik (IMBT) pada bank, bank berfungsi sebagai pihak penyedia uang atau modal untuk membiayai transaksi dengan menggunakan prinsip Ijarah muntahiya bit tamlik (IMBT) dengan membiayai penyewaan barang, kemudian barang sewa tersebut disewakan kembali kepada nasabah.

Sistem pembiayaan IB mikro syariah pada Bank DKI Syariah menggunakan sistem akad murabahah dan ijarah muntahiya bit tamlik, dimana pada sistem tersebut juga terdapat margin atau imbalan bagi hasil kepada pihak bank. Sistem margin yang digunakan pada pembiayaan IB mikro syariah ini berubah-ubah setiap bulannya, tergantung dengan kebijakan kantor pusat Bank DKI Syariah, dalam menentukan margin atau bagi hasil, pihak bank mendapatkan keuntungan dari rate yang sudah ditetapkan oleh kantor pusat Bank DKI Syariah, hitungannya adalah $15 \%$ dari efektivitasnya pertahun untuk menentukan margin, hal ini tergantung dari plafon, jika plafonnya di atas Rp. 100.000.000,00 maka margin tersebut berada diangka $15 \%$.

\section{Efektivitas Pembiayaan IB Mikro Syariah pada Bank DKI Syariah Cabang Depok dalam memberdayakan UMK Berbasis Syariah}

Efektivitas pada pembiayaan IB mikro syariah yaitu menekankan pada hasil yang dicapai, dengan melihat beberapa standar efektivitas yang harus dimiliki oleh nasabah penerima pembiayaan agar setelah menerima permodalan tersebut, nasabah dapat menjalankan usaha secara efektif dan mengalami kemajuan serta dapat melakukan pembayaran tanpa angsuran macet.

\section{Aspek Fungsi Pembiayaan}

Pembiayaan IB mikro syariah yang dijalankan Bank DKI Syariah Cabang Depok, yaitu sebagai pembiayaan kepada nasabah untuk modal Usaha Mikro Kecil (UMK) yang diharapkan dapat memberikan manfaat kepada nasabah penerima pembiayaan. Pemberian modal sebagai upaya pemberdayaan kepada nasabah, yaitu melalui permodalan usaha dengan memberikan kebutuhan yang diperlukan oleh nasabah tersebut, baik dalam pemenuhan pada kebutuhan modal kerja ataupun investasi berupa peralatan untuk usaha maupun pembelian tempat usaha dan lainnya.

Fungsi pada pembiayaan IB Mikro Syariah yang dijalankan Bank DKI Syariah Margonda Cabang Depok adalah sebagai suatu produk pembiayaan yang untuk layanan pembiayaan modal usaha bagi masyarakat, khususnya pada nasabah Bank DKI Syariah yang memiliki Usaha Mikro Kecil (UMK), sebagai upaya memberdayakan Usaha Mikro Kecil (UMK) dengan pemberian fasilitas berupa permodalan usaha yang didasarkan pada prinsip-prinsip syariah Islam dalam menciptakan peluang ekonomi untuk kelompok-kelompok Usaha Mikro Kecil (UMK) khususnya bagi nasabah Bank DKI Syariah Margonda Cabang Depok.

Pembiayaan IB Mikro Syariah dengan fungsinya, yaitu sebagai upaya pemberdayaan bagi permodalan usaha, telah dimanfaatkan secara langsung oleh nasabah pembiayaan ini.

Dengan demikian berdasarkan penjelasan di atas dapat disimpulkan bahwa, fungsi pada pembiayaan IB Mikro Syariah adalah sebagai pembiayaan yang dilakukan Bank DKI Syariah Cabang Depok yang difungsikan sebagai permodalan kepada nasabah Usaha Mikro Kecil (UMK) yang membutuhkan modal usaha seperti barang sembako dan kebutuhan lainnya dengan harapan dapat memberikan manfaat kepada penerima pembiayaan sebagai upaya pemberdayaan nasabah.

\section{Aspek Perencanaan Pembiayaan}

Perencanaan yang dilakukan dalam upaya memberdayakan Usaha Mikro Kecil (UMK) oleh Bank DKI Syariah Cabang Depok, yaitu bank harus terlebih dahulu mengetahui kebutuhan yang dibutuhkan oleh 
nasabah seperti kebutuhan pada penyediaan sembako bagi usaha penyedia bahan pokok, hal tersebut dilakukan agar bank mengetahui usaha nasabah sedang mempunyai kebutuhan di modal kerja atau pada investasi, baik itu yang diinvestasikan berupa perlengkapan kegiatan usaha bagi usaha atau pada pembelian tempat usaha dan lainnya.

Pihak bank tidak memberikan pelatihan kepada nasabah pembiayaan, akan tetapi memberikan edukasi kepada nasabah Usaha Mikro Kecil (UMK) sebelum dilakukannya akad, yaitu dengan memberikan pembinaan kepada nasabah terkait usaha dan pembiayaan yang akan dijalankan serta bank akan melakukan pengawasan secara bertahap terhadap produk usaha yang dijalankan nasabah. Hal tersebut dilakukan bank agar terciptanya suatu keberkahan dan dalam upaya mengantisipasi pembayaran macet oleh nasabah sesuai dengan tujuan akadnya.

Penerima pembiayaan adalah usaha yang telah berjalan selama lebih dari 2 tahun, hal tersebut dilakukan bank agar nasabah Usaha Mikro Kecil (UMK) penerima pembiayaan mempunyai usaha yang sudah siap dan matang. Bapak Aji selaku nasabah penerima pembiayaan telah menjalankan usaha toko ATK (Alat Tulis Kantor) selama kurang lebih 18 tahun.

Berdasarkan penjelasan di atas, pembiayaan yang dilakukan telah berjalan sesuai dengan perencanannya, dimana usaha nasabah yang melakukan pembiayaan pada Bank DKI Syariah telah berjalan lebih dari 2 tahun dan nasabah melakukan pelaporan rutin kepada pihak bank sebagai upaya monitoring usaha nasabah.

\section{Aspek Peraturan Pembiayaan}

Aspek peraturan pada pembiayaan IB Mikro Syariah, yaitu bersumber pada prinsip-prinsip syariah Islam dimana prinsip syariah menjadi pedoman pembiayaan yang dijalankan oleh bank. Nasabah penerima pembiayaan ini juga harus sesuai prinsip syariah Islam dan tidak mengandung unsur haram dalam menjalankan usahanya.
Usaha nasabah yang melakukan pembiayaan IB Mikro Syariah sudah sepenuhnya berprinsip syariah dan tidak ada unsur haram di dalamnya. Semua usaha yang dijalankan nasabah pembiayaan ini sudah sesuai dengan syariat Islam dan tidak mengandung unsur haram di dalamnya karena pihak bank selalu melakukan monitoring terhadap usaha nasabah sekitar 1 atau 3 bulan sekali.

Penjabaran yang didapatkan,
diketahui bahwa dalam perencanaan pembiayaan IB Mikro Syariah bank melakukan pembiayaan tersebut berdasarkan prinsip syariah Islam, serta nasabah pembiayaan ini juga sudah menjalakan usahanya sesuai dengan prinsip syariah Islam, dimana pada usahanya tersebut tidak mengandung unsur haram dan hal-hal yang dilarang oleh Islam.

\section{Aspek Tujuan Pembiayaan}

Aspek tujuan pada pembiayaan IB Mikro Syariah adalah sebagai produk pembiayaan usaha yang dilakukan Bank DKI Syariah Cabang Depok diperuntukkan bagi masyarakat Usaha Mikro Kecil (UMK) dalam memenuhi kebutuhan penambahan modal usaha, seperti penyediaan barang sembako pada usaha bahan pokok dan sebagainya yang telah sesuai dengan prinsipprinsip syariah Islam.

Tujuan pada pembiayaan ini adalah untuk memberikan permodalan usaha bagi Usaha Mikro Kecil (UMK) sebagai upaya menciptakan ekonomi bagi kelompok Usaha Mikro Kecil (UMK) sebagai upaya berbagi kegiatan pengentasan kemiskinan, perlindungan sosial dan secara perlahan dapat meningkatkan kualitas Sumber Daya Manusia (SDM) khususnya bagi kaum dhuafa. Tujuan nasabah dalam mengambil pembiayaan IB Mikro Syariah ini, yaitu untuk penambahan modal usaha yang sedang dijalankannya. Usaha yang dijalankan oleh nasabah pembiayaan IB Mikro Syariah sudah berdasarkan prinsip syariah dan pendapatan yang didapat mengalami peningkatan. 
Aspek tujuan pada pembiayaan IB Mikro Syariah telah sesuai dengan tujuannya, yaitu pihak bank memberikan permodalan usaha kepada nasabah Usaha Mikro Kecil (UMK) berdasarkan prinsip syariah Islam. Nasabah yang melakukan pembiayaan ini sudah sesuai tujuanya, dimana pendapatan meningkat dan Usaha Mikro Kecil (UMK) yang dijalankan sudah berprinsip syariah serta tidak ada unsur haram di dalam usahanya. Oleh karena itu, hal ini sejalan dengan teori yang dikemukakan oleh Farid (2017) bahwasannya Usaha Mikro Kecil (UMK) berbasis syariah merupakan usaha yang tidak terlepas dari prinsip syariah, sebagai bagian dari sistem ekonomi syariah.

Pemberdayaan Usaha Mikro Kecil (UMK) berbasis syariah serupa dengan penelitian Suwardi \& Boediningsih (2020), yang berjudul Tata Kelola Pengembangan UMKM Berbasis Syariah menyebutkan bahwa pemberdayaan pelaku UMKM berbasis syariah dalam melakukan bisnis dan usahanya tidak terlepas dari saringan syariah, maka dengan begitu usaha yang dijalankan tidak terkandung unsur haram di dalamnya (Suwardi dan Boediningsih, 2020).

\section{KESIMPULAN}

Sistem pembiayaan IB Mikro Syariah pada Bank DKI Syariah menggunakan 2 sistem akad, yaitu sistem pembiayaan akad murabahah dan akad ijarah muntahiya bit tamlik atau IMBT. Sistem akad murabahah pada pembiayaan IB Mikro Syariah, yaitu pihak bank membeli barang yang dibutuhkan nasabah, kemudian barang tersebut dijual kepada nasabah dengan harga barang ditambah dengan margin yang telah disepakati oleh kedua belah pihak. Sedangkan sistem akad ijarah muntahiya bit tamlik (IMBT) diterapkan ketika adanya nasabah yang mengajukan perpindahan pembiayaan dari bank syariah lain kepada Bank DKI Syariah. Pembiayaan IB Mikro Syariah pada Bank DKI Syariah Cabang Depok dalam memberdayakan nasabah UMK berbasis syariah diukur dengan menggunakan 4 aspek, yaitu aspek fungsi pembiayaan, aspek perencanaan pembiayaan, aspek peraturan pembiayaan dan aspek tujuan pembiayaan.

\section{DAFTAR PUSTAKA}

Bakulu, B., Pangkey, M, \& Kolondam, H. 2021. Efektivitas Program Keluarga Harapan Sektor Pendidikan Di Desa Hatetabako Kecamatan Wasile Tengah Kabupaten Halmahera Timur. Jurnal Administrasi Publik, 7(101), p. 18-28.

Chasanah, N. U., Ilmiyah, D, \& Rahmatika, A. N. 2020. Penerapan Akad Ijarah Muntahiya Bittamlik (IMBT) di Bank BRI Syariah KCP Jombang. REVENUE : Jurnal Ekonomi Pembangunan Dan Ekonomi Syari'ah, 02(01), p. 47-56.

Dzubyan, D. M., Azzahra, E, \& Puspitasari, M. 2017. Analisis Akad Ijarah Muntahiya Bittamlik (IMBT) dalam Perspektif Hukum Islam dan Hukum Posistif Di Indonesia. Amwaluna : Jurnal Ekonomi dan Keuangan Syariah, 53(9), p. 181-196.

Farid. 2017. Kewirausahaan Syariah. Kencana. Depok.

Felani, Herman., \& Setiawani, Inta Gina. 2016. Pengaruh Pendapatan Mudharabah, Musyarakah Dan Murabahah Terhadap Profitabilitas Pada Bank Umum Syariah Periode 2013 2015. Seminar Nasional dan The 4th Call for Syariah Paper, p. 1-17.

Hidayati, N. 2018. Pengaruh Pembiayaan Syariah Kepada Usaha Mikro Kecil Menengah (UMKM) Terhadap Perkembangan Perekonomian Di Jawa Timur. Retrieved from : NIFTI HIDAYATI (166120600030).pdf (umsida.ac.id).

Imronah, S. 2019. Pengembangan Usaha Nasabah UMKM (Studi Pada BRI Syariah KCP Metro). Skripsi IAIN Metro.

Kementerian Koperasi dan UKM RI. 2020. Sektor UMKM Jadi Kunci Pemulihan Di Tengah Pandemi. Depkop.Go.Id.

Kementerian Perdagangan. 2013. Analisis 
Peran Lembaga Pembiayaan Dalam Pengembangan UMKM. Pusat Kebijakan Perdagangan Dalam Negeri, 90.

Khoeriyah. 2016. Pembiayaan Bank Syariah. Gramedia Pustaka Utama. Jakarta.

Muasaroh. 2010. Aspek-aspek Efektifitas studi Tentang Efektifitas Pelaksanaan Program Pelaksanaan PNPM-MP. Skripsi. Universitas Brawijaya.

Muheramtohadi, S. 2017. Peran Lembaga Keuangan Syariah dalam Pemberdayaan UMKM di Indonesia. MUQTASID Jurnal Ekonomi Dan Perbankan Syariah, 8(1), p. 65-77.

Murdaningsih, D. 2019. UMKM Dinilai Lebih Cocok dengan Sistem Syariah. Di kutip dari : Republika.Co.Id.

Ratnawati, Any., \& Mursid, Mansur Chadi 2011. Potensi dan Strategi Pengembangan Bank Syariah di Indonesia: Kajian Produk Syariah dari Segi Fiqih Muamalat. Jurnal Hukum Islam, 9(2), p. 251-271.

Permana, S. H. 2017. Strategi Peningkatan Usaha Mikro, Kecil, Dan Menengah (Umkm) Di Indonesia. Aspirasi: Jurnal Masalah-masalah Sosial, 8(1), p. 93103.

Ramadhani, D. 2019. Ekonomi Islam Akuntansi dan Perbankan Syariah. Markumi. Indonesia.

Saragih, F. H. 2017. Pembiayaan Syariah Sektor Pertanian. Jurnal Agrica, 10(2), p. 112-118.

Satria, M. R. 2018. Analisis Perbandingan Pemberian Kredit Pemilikan Rumah (KPR) Pada Bank Konvensional Dengan Pembiayaan Murabahah (KPR) Pada Bank Syariah. Amwaluna: Jurnal Ekonomi Dan Keuangan Syariah, 2(1), p. 107-117.

Sofyan, I. 2019. UMKM Syariah: Arah Baru Membangun Industri Halal. Di kutip dari : Medanbisnisdaily.
Suwardi, \& Boediningsih, W. 2020. Tata Kelola Pengembangan Usaha UMKM Berbasis Syariah. Jurnal HUKUM BISNIS, 4(1).

Weya, K., Areros, W. A., \& Tumbel, T. M. 2020. Analisis Perilaku Usaha Mikro Kecil (UMK) di Kabupaten Tolikara Propinsi Papua. Productivity, 1(3), p. 267-273. 